\title{
PROCEDURALIZING THE ART OF CLINICAL SKILLS TEACHING
}

\author{
Sateesh Babu, Arja *, Simi Paramban, Kumar Ponnusamy, Praveen Kottathveetil, \\ Tarig Fadlallah Altahir Ahmed, Sireesha Bala Arja.
}

Avalon University School of Medicine (AUSOM), Curacao.

\section{ABSTRACT}

Purpose: Literature suggests that there are two common teaching methods in clinical skills are the four-step approach of Peyton and the theory of instructional design by Gagne. The combination of these two teaching methods was planned and implemented in the undergraduate medical program at Avalon University, Curacao, in training and teaching clinical skills during the firsttwo years of the program. The objective behind developing this teaching modality is to offer more chances to repeat the demonstration by the instructors, to rehearsal by students, and to provide instant feedback on specific concepts of clinical skills. This study aims to examine further and evaluate this teaching method for clinical skills.

Methods: This is a quasi-experimental study that was conducted to evaluate the new teaching method. The data were gathered in summer 2017, which is a control group and for another three groups; fall 2017, winter 2018, and summer 2018, which are study groups. A survey of course evaluations was developed to collect both qualitative and quantitative feedback from students at the end of the course. The quantitative questionnaire included 17 questions used a five-point Likert scale with one of the following responses; one indicates strongly disagree, two-disagree, three-neutral/no opinion, four-agree, and five-strongly agree. Qualitative analysis was done based on the responses from students for open-ended questions. Quantitative data were gathered even for students' grades on the final assessments.

Results: Students' responses (survey questionnaire) data were analyzed for descriptive statistics. The response rate for the summer 2017 group (control) is $100 \%$ and $95.65 \%, 87.5 \%$, and $90.9 \%$ for the three study groups, respectively. Students' feed back for all questions showed improved satisfaction with the new method of teaching. The class performance (mean grade) of different groups wasshown a difference which is statistically significant $(p<0.05)$ on the Kruskal-Wallis test.

Conclusion: The new modality of teaching in clinical skills showed that students are more satisfied and also improved students' performance.

KEYWORDS: Clinical Skills, Assessment, Feedback, Teaching, Evaluation.

Address for correspondence: Dr. Sateesh Babu Arja, M.B.B.S, MHPE, MSPH, FAMEE, SFHEA, FIAMSE, FAcadMEd, Director of Clinical Skills, Avalon University School of Medicine, Willemstad, Curacao Phone number-011-599-96965682 E-Mail: sarja@avalonu.org

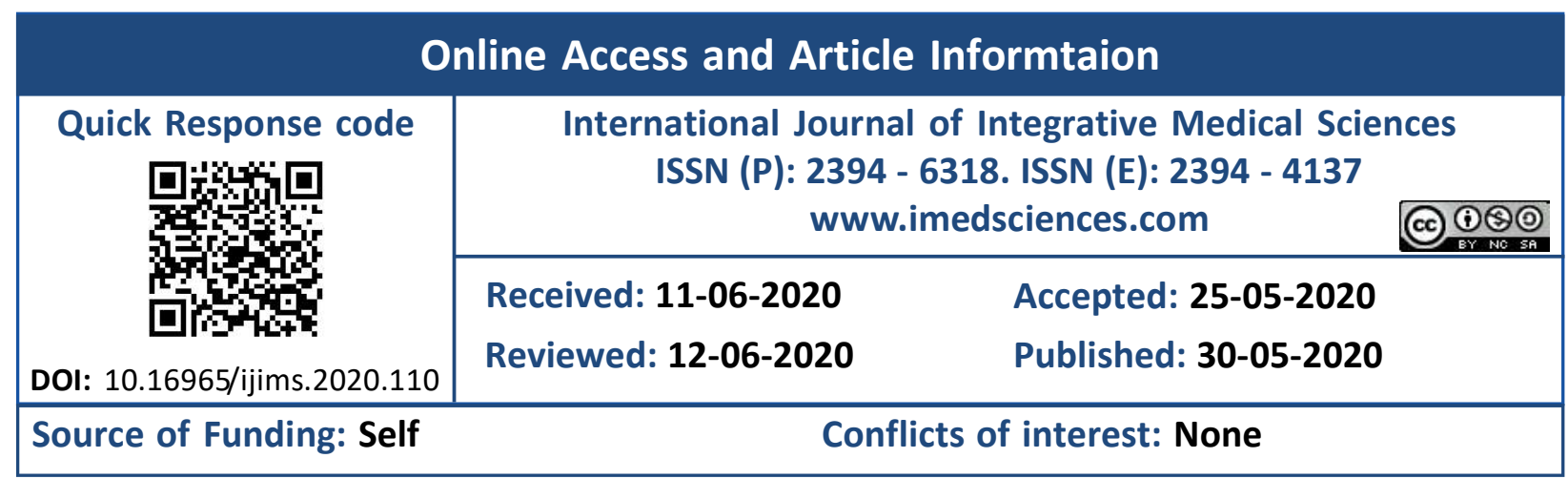

\section{INTRODUCTION}

One common practice of teaching and training clinical skills is the four-step approach of Peyton [1], which was initiated from one of the chapters in a book focused on teaching in operation theatres. The four-steps include instructor demonstrating the skills, and then instructor demonstrating the same skills with commentary. Then it is followed with the demonstration driven by students, and finally, students practice or exhibit the skills with an explanation. Another known teaching and training methodology for clinical skills training was developed by Robert Gagne(1977) and 
included nine steps. The nine steps as quoted in the learning theory by Gagneare "gaining learner attention, informing the learner of the objective, stimulating prior recall, presenting distinctive stimulus features (demonstrate), learning guidance for the encoding of information (individualizing the learning), eliciting performance (practice), providing feedback, assessing performance, and enhancing retention and transfer." [2].

The major learning theories supporting these methods of training clinical skills are classified into active adult learning theory, behaviorism, and constructivism. In the behavioral approach, students are repeatedly practicing the skills until they master theirabilities. As Race and Brown quoted, "the critical factors in behavioral learning theory arestimulus, feedback, and reward. Demonstrating the skills is the input, and learned behaviors are the output"[3]. Behavioral learning theory appears to be the primary basis for the current approaches to teaching clinical skills.

Background of new teaching method: The majority of medical schools are teaching clinical skills as part of the curriculum in the pre-clerkship years of the educational program. The purpose of clinical skills training and teaching are acquiring physical examination skills, soft skills like communication, clinical reasoning, and professional behaviors required of students to enter into clinical rotations and to enter into the practice of medicine as future physicians. The assessment of students in clinical reasoning and skills during the initial years of the medical school has a long-term effect on students' performance in clinical rotations and postgraduate level training [4]. But still, there is no one method of clinical skills teaching in literature shown the optimal method of clinical skills training.

To address this, we developed the hybrid model for teaching clinical skills (a combination of Peyton's method and Robert Gagne's method) in the undergraduate medical program at Avalon University School of Medicine (AUSOM). We implemented it in the semester offall of 2017. The new teaching method includes eight steps; informing the learner of the objectives, group discussions and recall of prior biomedical sciences, demonstration of skills on standardized patients with PowerPoint and/or audiovisual aids, demonstration of skills on standardized patients with the explanation but no audio-visual aids or PowerPoint, students practice in groups, demonstration of skills in front of the instructor by students, assessment, and feedback. This study furtherexamines and evaluatesthe new practice of teaching clinical skills, which was published in the Journal of Advances in Medical Education and Professionalism (JAMP) as "The hybrid model of clinical skills teaching and the learning theories behind it" [5]. The previous publication that was published in JAMP [5] had two cohorts of study groups, but in this current study, we had three cohorts of study groups.

Eight-steps involved in the hybrid model/new method of clinical skills teaching

Informing the learner of the objectives: The session starts by defining the learning objectives of the session. It is advised not to use too many negative comments. For example, do not say that physical examination of central nervous system is the longest one. Do not make objectives also too easy. Instead, the session will start by saying that the physical examination of the central nervous system is an interesting one.

Group discussions and recall of prior biomedical sciences: Then students will be engaged in group discussions recalling the previous knowledge of basic sciences. The instructor facilitates these group discussions. If the cardiovascular system is covered in clinical skills, students are engaged in conversations like the cardiac cycle and valvular heart diseases, etc. There will be further discussion about hypertension, coronary artery diseases, and heart failure, etc. If the respiratory system is covered in clinical skills, there will be discussions regarding lung volumes, pneumonia, and abnormalities of the lung volumes in restrictive lung diseases, asthma, and chronic obstructive lung diseases, etc. These discussions are based on the concepts of previous knowledge and experiences and gaining new knowledge and experiences (constructive learning theory).

Demonstration with commentary and audiovisual aids and PowerPoint: The instructor 
demonstrates the physical examination using standardized patients with PowerPoint and other audiovisual aids as required.

Demonstration with commentary but no PowerPoint: The instructor demonstrates the clinical skills again on standardized patients with the explanation but without audiovisual aids.

Practice by groups of students and feedback is provided instantly: Students are formedinto groups, and each group consists of four or five students. They practice the clinical skills and communication skills on standardized patients. Each group has a group leader and facilitator (learners). The responsibility of the group leader is to make sure everyone is engaged in the practice sessions. The purpose of the facilitator is to facilitate the process, and all steps are followed accurately. The role of the instructor at this stage is to supervise the process. The instructor also provides the feedbackas and when required. The feedback does not offer only the corrective information but also equipped with positive reinforcement.

Demonstration of skills in front of the instructor by students: After practicing two times, learners perform the physical examination and other skills in front of the instructor. At this point, they are also provided with feedback.

Assessment: Students are assessed on summative assessments using a single station standardized patient-based assessment for the comprehensive history and physical examination. This assessment used is validated by Miller's learning pyramid, "student shows" level[6].

Feedback: Students are provided with feedback after the formative and summative assessments.

\section{METHODS}

This is a quasi-experimental study to evaluate the new instruction method after implementation. No randomization was involved. In the fall of 2017, we introduced the mixed method of training clinical skills, which is a combination of Peyton's method and Robert Gagne's approach. The class immediately prior, the MD2 class of summer 2017, received the conventional teaching method, and this class population served as the control group. All study groups (fall 2017, winter 2018, and summer 2018) were compared with the control group. Both qualitative and quantitative data had been gathered after the implementation of the Hybrid Model. The Kirkpatrick model of evaluation $[7,8]$ was used to evaluate the newly implemented instructional method, and weaimed to evaluate at two levels including;

\section{- Reaction: Feedback from students \\ - Learning: Student performance data}

At the endof the semester/course, students' feedback questionnaire (survey form) was developed to collect both qualitative and quantitativeresponses. Written and fully informed consent was taken from the participants. All students had a right to decline participation in the study, and participation was voluntary. Thequantitative questions had a Likert scale with the following responses available; one is strongly disagreeing, two-disagree, three-neutral or no opinion, four-agree, and five-strongly agree. Open-ended questionsfor qualitative analysis were included in determining if any further improvements requiredand if the students feel that this course is worth of recommending to other learners. Students were requested to state the constructive feedback to improve the course's weaknesses and strengths using open-ended questions.

The survey was conducted using survey monkey by the Informational Technology (IT) department of AUSOM. The participation of the students was voluntary and anonymous. The responses were analyzed after the IT department collected responses. Personal information of the students was not identified throughout the study and analysis of the results. The survey was conducted after the grades were submitted at the end of the semester. Students' grades/performance on final assessments of the three study groups were compared with those of the control group.

\section{RESULTS}

Participants included all second-semester students of the Doctor of Medicine (M.D.) program (MD2) who are enrolled in the clinical skills-Il course at AUSOM. The study population was diversified and represented of the AUSOM population at large (see Table 1). 
Table 1: Cohort Demographics.

\begin{tabular}{|c|c|c|c|c|c|c|c|}
\hline & & \multicolumn{2}{|c|}{ Biological Sex } & \multicolumn{4}{|c|}{ Race or Ethnicity } \\
\hline Cohort & Total \# & female & male & Caucasian & Hispanic & African & Asian \\
\hline $\begin{array}{c}\text { summer 2017 } \\
\text { control Group }\end{array}$ & 26 & 13 & 13 & 2 & 0 & 3 & 21 \\
\hline $\begin{array}{c}\text { fall 2017 } \\
\text { Study Group }\end{array}$ & 24 & 10 & 14 & 2 & 0 & 2 & 20 \\
\hline $\begin{array}{c}\text { winter 2018 } \\
\text { Study Group }\end{array}$ & 16 & 3 & 13 & 2 & 0 & 4 & 10 \\
\hline $\begin{array}{c}\text { summer 2018 } \\
\text { Study Group }\end{array}$ & 11 & 6 & 5 & 0 & 1 & 2 & 8 \\
\hline
\end{tabular}

Table 2:Descriptive statistics of students' feedback for quantitative questions oncourse evaluations given at the end of the semester.

\begin{tabular}{|c|c|c|c|c|c|c|c|c|}
\hline \multirow[t]{2}{*}{ Item } & \multicolumn{2}{|c|}{$\begin{array}{c}\text { summer } 2017 \\
\text { traditional instruction } \\
\text { (control group) } \mathrm{N}=\mathbf{2 6}\end{array}$} & \multicolumn{2}{|c|}{$\begin{array}{l}\text { fall } 2017 \text { new method } \\
\text { of instruction (study } \\
\text { group) } \mathrm{N}=22\end{array}$} & \multicolumn{2}{|c|}{$\begin{array}{c}\text { winter } 2018 \text { new } \\
\text { method of instruction } \\
\text { (study group) } N=14\end{array}$} & \multicolumn{2}{|c|}{$\begin{array}{l}\text { summer } 2018 \text { new } \\
\text { method of instruction } \\
\text { (study group) } N=10\end{array}$} \\
\hline & Median & Mode & Median & Mode & Median & Mode & Median & Mode \\
\hline $\begin{array}{l}\text { The Instructor stimulated student's } \\
\text { interest in the subject }\end{array}$ & 4 & $4 \& 5$ & 5 & 5 & 5 & 5 & 5 & 5 \\
\hline $\begin{array}{l}\text { The instructor managed classroom time } \\
\text { and pace well }\end{array}$ & 4 & 4 & 5 & 5 & 5 & 5 & 5 & 5 \\
\hline $\begin{array}{l}\text { The instructor was organized and } \\
\text { prepared for every class }\end{array}$ & 4 & 4 & 5 & 5 & 5 & 5 & 5 & 5 \\
\hline $\begin{array}{l}\text { The instructor encouraged discussions } \\
\text { and responded to questions }\end{array}$ & & 4 & 5 & 5 & 5 & 5 & 5 & 5 \\
\hline $\begin{array}{l}\text { The instructor demonstrated in-depth } \\
\text { knowledge of the subject }\end{array}$ & & 4 & 5 & 5 & 5 & 5 & 5 & 5 \\
\hline $\begin{array}{l}\text { The instructor appeared enthusiastic and } \\
\text { interested }\end{array}$ & 4 & 4 & & 5 & 5 & 5 & 5 & 5 \\
\hline $\begin{array}{l}\text { The instructor used a variety of } \\
\text { instructional methods to reach the course } \\
\text { objectives e.g., group discussions, } \\
\text { audiovisual aids, \& Standardized Patient } \\
\text { program, etc. }\end{array}$ & 4 & 4 & & & 5 & 5 & 5 & 5 \\
\hline $\begin{array}{l}\text { Please rate the overall quality of the } \\
\text { Class/ Instructor }\end{array}$ & 4 & 5 & 5 & 5 & 5 & 5 & 5 & 5 \\
\hline $\begin{array}{l}\text { Information about the assessment was } \\
\text { communicated clearly. }\end{array}$ & 4 & 5 & 5 & 5 & 5 & 5 & 5 & 5 \\
\hline $\begin{array}{l}\text { Feedback was provided within the stated } \\
\text { time frame. (Providing the rationale). }\end{array}$ & 4 & $4 \& 5$ & 5 & & 5 & 5 & 5 & 5 \\
\hline $\begin{array}{l}\text { Feedback showed how to improve my } \\
\text { work }\end{array}$ & 4 & 4 & 5 & 5 & 5 & 5 & 5 & 5 \\
\hline The course objectives were clear & 4 & 5 & 5 & 5 & 5 & 5 & 5 & 5 \\
\hline $\begin{array}{l}\text { The course procedures and assignments } \\
\text { support course objectives }\end{array}$ & 4 & 4 & 5 & 5 & 5 & 5 & 5 & 5 \\
\hline $\begin{array}{l}\text { The instructor gave guidance on where to } \\
\text { find resources }\end{array}$ & 4 & 5 & 5 & 5 & 5 & 5 & 5 & 5 \\
\hline $\begin{array}{l}\text { Overall, how student's experience in this } \\
\text { course }\end{array}$ & 3 & 3 & 5 & 5 & 5 & 5 & 5 & 5 \\
\hline $\begin{array}{l}\text { Student contributed constructively to in- } \\
\text { class activities. }\end{array}$ & 4 & 4 & 5 & 5 & 4 & 4 & 5 & 5 \\
\hline $\begin{array}{l}\text { Student's perception of achieving course } \\
\text { learning objectives }\end{array}$ & 4 & 4 & 5 & 5 & 5 & 5 & 5 & 5 \\
\hline
\end{tabular}

Students' response for end-of-semester/course evaluationsfor the control group (summer 2017) were $n=26$ with a response rate of $100 \%$. The response rate for the study group of fall 2017 was $92 \%$ (22 out of 24 ), and the response rate for another study group of winter 2018 was $87 \%$ (14 out of 16). The response rate for the laststudy group was $91 \%$ (10 out of 11 students).
The responses were analyzed for median, mode, and mean (descriptive statistics). Median, mode, and mean were calculated using SPSS software. The mean, median, and mode showed improvement with the new method of clinical skills teaching compared with the conventional (traditional) teaching method. Mean, median, and mode are represented in the following tables. 
Table 3: Mean of students' responses for quantitative questions on end of the semester/course evaluations.

\begin{tabular}{|c|c|c|c|c|}
\hline Item & $\begin{array}{c}\text { summer } 2017 \\
\text { traditional } \\
\text { instruction } \\
\text { (control group) } \\
\mathrm{N}=26\end{array}$ & $\begin{array}{l}\text { fall } 2017 \text { new } \\
\text { method of } \\
\text { instruction } \\
\text { (study group) } \\
\quad \mathrm{N}=22\end{array}$ & $\begin{array}{c}\text { winter } 2018 \\
\text { new method of } \\
\text { instruction } \\
\text { (study group) } \\
\mathrm{N}=14\end{array}$ & $\begin{array}{c}\text { summer } 2018 \\
\text { new method of } \\
\text { instruction } \\
\text { (study group) } \\
\mathrm{N}=10\end{array}$ \\
\hline $\begin{array}{l}\text { The Instructor stimulated student's interest in the } \\
\text { subject }\end{array}$ & $4.00( \pm 1.1)$ & $4.80( \pm 0.40)$ & $4.799( \pm 0.56)$ & $4.88( \pm 0.33)$ \\
\hline $\begin{array}{l}\text { The instructor managed classroom time and pace } \\
\text { well }\end{array}$ & $4.15( \pm 1.03)$ & $4.75( \pm 0.43)$ & $4.79( \pm 0.56)$ & $4.88( \pm 0.33)$ \\
\hline $\begin{array}{l}\text { The instructor was organized and prepared for } \\
\text { every class }\end{array}$ & $4.08( \pm 1.00)$ & $4.75( \pm 0.43)$ & $4.71( \pm 0.59)$ & $4.88( \pm 0.33)$ \\
\hline $\begin{array}{l}\text { The instructor encouraged discussions and } \\
\text { responded to questions }\end{array}$ & $4.08( \pm 0.83)$ & $4.68( \pm 0.46)$ & $4.71( \pm 0.59)$ & $4.88( \pm 0.33)$ \\
\hline $\begin{array}{l}\text { The instructor demonstrated in-depth knowledge } \\
\text { of the subject }\end{array}$ & $4.31( \pm 0.46)$ & $4.79( \pm 0.41)$ & $4.69( \pm 0.61)$ & $4.88( \pm 0.33)$ \\
\hline $\begin{array}{l}\text { The instructor appeared enthusiastic and } \\
\text { interested }\end{array}$ & $4.15( \pm 0.66)$ & $4.58( \pm 0.59)$ & $4.64( \pm 0.61)$ & $4.88( \pm 0.33)$ \\
\hline $\begin{array}{l}\text { The instructor used a variety of instructional } \\
\text { methods to reach the course objectives e.g., } \\
\text { group discussions, audiovisual aids, \& } \\
\text { Standardized Patient program.etc. }\end{array}$ & $4.23( \pm 0.58)$ & $4.74( \pm 0.44)$ & $4.57( \pm 0.62)$ & $4.63( \pm 0.48)$ \\
\hline $\begin{array}{l}\text { Please rate the overall quality of the Class/ } \\
\text { Instructor }\end{array}$ & $4( \pm 1.18)$ & $4.58( \pm 0.67)$ & $4.79( \pm 0.56)$ & $4.75( \pm 0.66)$ \\
\hline $\begin{array}{l}\text { Information about the assessment was } \\
\text { communicated clearly. }\end{array}$ & $3.92( \pm 1.14)$ & $4.63( \pm 0.48)$ & $4.64( \pm 0.61)$ & $4.88( \pm 0.33)$ \\
\hline $\begin{array}{l}\text { Feedback was provided within the stated time } \\
\text { frame. (Providing the rationale). }\end{array}$ & $3.69( \pm 1.20)$ & $4.63( \pm 0.48)$ & $4.71( \pm 0.59)$ & $4.68( \pm 0.40)$ \\
\hline Feedback showed how to improve my work & $3.46( \pm 1.34)$ & $4.47( \pm 0.68)$ & $4.57( \pm 0.62)$ & $4.68( \pm 0.40)$ \\
\hline The course objectives were clear & $3.77( \pm 1.37)$ & $4.68( \pm 0.46)$ & $4.64( \pm 0.61)$ & $4.75( \pm 0.43)$ \\
\hline $\begin{array}{l}\text { The course procedures and assignments support } \\
\text { course objectives }\end{array}$ & $3.92( \pm 1.33)$ & $4.63( \pm 0.48)$ & $4.71( \pm 0.59)$ & $4.75( \pm 0.43)$ \\
\hline $\begin{array}{l}\text { The instructor gave guidance on where to find } \\
\text { resources }\end{array}$ & $4.15( \pm 0.77)$ & $4.63( \pm 0.48)$ & $4.64( \pm 0.61)$ & $4.63( \pm 0.70)$ \\
\hline Overall, how student's experience in this course & $3.62( \pm 1.15)$ & $4.74( \pm 0.64)$ & $4.79( \pm 0.56)$ & $4.75( \pm 0.66)$ \\
\hline $\begin{array}{l}\text { Student contributed constructively to in-class } \\
\text { activities. }\end{array}$ & $4.23( \pm 0.70)$ & $4.68( \pm 0.46)$ & $4.36( \pm 0.61)$ & $4.50( \pm 0.50)$ \\
\hline $\begin{array}{l}\text { Student's perception of achieving course learning } \\
\text { objectives }\end{array}$ & $4( \pm 0.88)$ & $e^{4.68( \pm 0.57)}$ & $4.50( \pm 0.63)$ & $4.63( \pm 0.48)$ \\
\hline
\end{tabular}

Table 4: Students' performance on summative assessments.

\begin{tabular}{|c|c|c|}
\hline Group & Mean & Range \\
\hline $\begin{array}{c}\text { summer 2017 control group } \\
(\mathbf{n = 2 5 )}\end{array}$ & 81.04 & $97-70=27$ \\
\hline $\begin{array}{c}\text { fall 2017 study Group (n=23) } \\
\text { winter 2018 Study Group } \\
(\mathbf{n = 1 6 )}\end{array}$ & 93.13 & $100-71=29$ \\
\hline $\begin{array}{c}\text { summer 2018 Study Group } \\
\text { (n=11) }\end{array}$ & 95.27 & $100-84=16$ \\
\hline
\end{tabular}

In the previous publication that was published in JAMP [5] had two cohorts of study groups, and the data was analyzed using ANOVA test as variance among the three groups (one control group and two study groups) was homogenous. In the previous study, the data satisfied the assumption of parametric tests. But in this current study, we had three cohorts of study groups, and variance among four groups was not homogenous. We employed the Kruskal-Wallis test as the variance was non-homogenous across the groups to compare students' performance on summative assessments.Students who were withdrawn voluntarily before ten weeks of the course and or students who didn'tmake the final assessments were not included in the statistical analysis. There was a statistical significance with the $p$-value 0.0001 ( $p$-value is less than 0.05).

\section{DISCUSSION}

The analysis showed that there is an improvement of mean, median, and mode for questions number 1 to 8 with the new method of clinical skills teaching compared to the conventional method of teaching. All questions from 1 to 8 are related to teaching methods including students' interest in the subject was stimulated by the instructor, discussions were encouraged 
by the instructor and responded to questions, the instructor did use a different methods of teaching, and the students' rating for the overall quality of the classinstructor. This shows that students' satisfaction has been improved with the new method of teaching clinical skills as the same instructor was involved in teaching this course module across all semesters for the group that received conventional teaching methods (control group) and all study groups. One of the reasons why students are satisfied with the hybrid clinical skills teaching method is the instructor demonstrates skills at least two times.

There is an improvement of mean, median, and mode for questions 9 to 13 with the new method of clinical skills teaching compared to the conventional method of teaching. All questions from 9 to 13 are related to the assessments, and providing feedback including feedback was provided in a timely manner, feedback helped how to improve students' work, and the course assessments and assignments are in support of course objectives. One of the reasons students are satisfied with the feedback provided is that the hybrid model of clinical skills offers many opportunities to provide feedback to the students. Feedback can be provided when students are practicing in groups, after students exhibit their skills in front of the instructor, and after the summative assessments. The literature suggests that the most effective feedback is provided within the time frame[9] and specific. Also, research indicates that feedback provided after summative assessments or OSCE can improve the students' experiences in future practice, even though it might not be helpful for future assessments or for changing students' learning behavior. Students are happy with the availability of feedback (feedback was provided in a timely manner) and the adequacy of feedback (feedback helped on how to improve students' work).

The analysis also showed an improvement of mean, median, and mode for questions number 14 to 17 with the new method of clinical skills teaching compared to the conventional method of teaching with one exception. All questions from 14 to 17 are related to overall student's overall educational experience in the course, students' constructive participation in classroom activities, and students' perception that they are accomplishing the course's learning objectives. The one exception that we identified is for question number 16 , which is regarding student's constructive participation inclassroom activities. Students' response to this question for the winter 2018 semester was dropped to 4 compared with 5 for the fall 2017 semester. We identified the reason by qualitatively analyzing the responses or comments of students. Students would like to have more standardized patients per each class. The course instructor took care of it by increasing the number of standardized patients by one. Students' responsesto this question rose to 5 again for the summer 2018 semester.

The other question which is noteworthy to be identified is question 15 regarding how student's overall experience in this course. For this question, students' ratings were 3 for summer 2017 semester with the conventional method of teaching. But ratings increased for all three study groups to 5 with the hybrid model of teaching.

Students' performance on final assessments was compared across the groups on the KruskalWallis test. There was an improvement with a statistically significant $p$-value 0.0001 ( $p$-value is less than 0.05). It showed that the improvement is statistically significant with the hybrid model of teaching clinical skills.

Students' responses for open-ended questions were analyzed, and they were themed into the following categories. Students were also asked if they feel this course is worthy, and they recommend this course to other students.

Teaching: All students appreciated the new method hybrid model of the clinical skills teaching method. Especially students acknowledged the instructor for demonstrating the skills in this class. Here is one of the quotes from students regarding the demonstration by the instructor.

"Instructorshowed an in-depth knowledge of everything and was great and helping us understand it. No matter how many times he had to go over something, he made sure we not onlyunderstood it but remembered it. Giving us helpful tips and tricks along the way to help us withour clinical skills exam, other exams we are 
currently taking, and as well as our Step $1 / 2$ exams, which wewill all eventually take. Instructor going over the entire physical examination skills in front of the class twice whileexplaining everything and his willingness to repeat himself and go over things with you again reallyhelped me succeed in his class. He also challenges you to do better, but at the same time,motivating you to want to do better and helping you to do better, rather than just leaving you tofigure it out on your own. Clinical skills used to be a class that gave me stress because sometimes I thoughtl was lost or behind, but the instructor did everything to make sure I was caught up and up to speedwith everything."

\section{Here is another quote}

"The instructor taught the course very well. I enjoyed this class. I learned not only the material for clinical skills but along with it for other classes."

At AUSOM, the clinical skills course runs parallel with other basic science courses in the first two years of the program. The students' knowledge of biomedical sciences can help them with the clinical skills course. But students also complimented that the clinical skills course could help in understanding other basic sciences courses like Human Structure and Function (HSF) course. Here are some quotes from the students. "Taught concepts of HSF subjects as well in contrast with only clinical skills beneficial for all subjects and very well delivered to students."

"I loved how the teacher incorporated the pathophysiology at the beginning, so we understand the topic better."

"Instructor's way of summarizing the systems and compiling all important information (of all subjects) in a short time and explaining it amazingly. Keeping it realistic for the students to achieve goals, his expectations were never unrealistic."

Assessments and Feedback: Students were pleased with the assessments. They were satisfied with the effective feedback provided within the time frame and multiple opportunities to receive the feedback. Multiple opportunities and resources are available for students to receive feedback. Here are some quotes regarding the assessments and feedback.
"Love the way he gives feedback to the students. $\mathrm{He}$ is good at it. He is a very friendly and approachable teacher."

"I feel like the feedback I got from the instructor, my classmates, and the standardized patients themselves helped me improve a lot."

Improvements: Students were asked to comment if this is a good class. $100 \%$ of students from study groups reported that this is a class of worthy, and they could recommend this course to other learners. No further improvements required were reported on survey forms.

Limitations: Sample size is one of the limitations of this study. The sample size is small in this study. We did publish a manuscript in the past on this teaching method hybrid model of teaching with two study groups fall $2017(n=23)$ and winter $2018(n=16)$. But we continued our evaluation in summer $2018(n=11)$ to further validate this teaching method. This teaching method can be applied even for the bigger classes witha large number of students if one instructor is provided for every 10-15 students and instructors are appropriately trained for this teaching method.

Take home Message:Not only teaching clinical skills, but the way educators teach clinical skills to play an essential role in training undergraduate medical students to prepare them for graduate education.

- The hybrid model of teaching clinical skills shown to be effective for small-size classes.

- This new method of teaching clinical skills can also be effective for the large-size classes provided with enough instructors, and they receive appropriate faculty development activities.

\section{CONCLUSION}

Teaching and training clinical skills became an essential part of medical education curricula. The assessments and training in clinical skills can have an impact on students' performance in clinical clerkships and performance on the Step 2CS exam. Even though clinical skills are taught as a course at most of the medical schools, there is a requirement to find out the best practices of teaching and training clinical skills to accomplish the objectives of teaching clinical skills. The hybrid method of teaching 
clinical skills is shown to be effective for small class sizes. But it can be effectively implemented with a large number of students if one instructor is provided for every 10-15 students.

\section{ACKNOWLEDGEMENT}

The authors would like to acknowledge the educational and fellowship committee of the International Association of Medical Science Educators (IAMSE), Dr. Amber Heck, and Dr. Paula Smith. The results of this study were presented at the 23rd Annual Meeting of IAMSE, Roanoke, USA, June 8-11, 2019.

\section{REFERENCES}

[1]. Peyton JWR. Teaching and Learning in Medical Practice. 1998, Rickmansworth: Manticore Europe.

[2]. Gagné RM. The Conditions of Learning. 1977, New York: Holt, Rinehart and Winston.

[3]. Race P, Brown S. The Lecturer's Toolkit. 1998, London: Kogan Page.

[4]. LaRochelle JS, Dong T, Durning SJ. Preclerkship assessment of clinical skills and clinical reasoning: the longitudinal impact on student performance. Mil Med.2015;180(4 Suppl):43-6.https://doi.org/ 10.7205/MILMED-D-14-00566 PMid:25850125
[5]. Sateesh Babu Arja, SireeshaBalaArja, Samir Fatteh. The hybrid model of clinical skills teaching and the learning theories behind it. Journal of Advances in Medical Education and Professionalism (JAMP), 2019;7(3):111-117.

[6]. Miller GE. The assessment of clinical skills/ competence/performance. Academic Medicine1990; 65:563-7.https://doi.org/10.1097/00001888199009000-00045 PMid:2400509

[7]. Kirkpatrick DL. Evaluating training programmes: The four levels. 1998, Philadelphia: Berrett-Koehler.

[8]. Kirkpatrick DL. Techniques for evaluation programsPart 2: Learning. Journal of the American Society of Training Directors; 1959;13(12):21-6.

[8]. Norcini,J, Burch V. Workplace-based assessment as an educational tool: AMEE Guide No. 3. Medical Teacher; 2007;29:855-71.https://doi.org/10.1080/ 01421590701775453 PMid:18158655

How to cite this article: Sateesh Babu, Arja, Simi Paramban, Kumar Ponnusamy, PraveenKottathveetil,TarigFadlallahAltahir Ahmed,SireeshaBalaArja. PROCEDURALIZING THE ART OF CLINICAL SKILLS TEACHING. Int J Intg Med Sci 2020;7(5):905-913. DOI: 10.16965/ijims.2020.110 